\title{
The Philosophy on the Relationship Between Humans and the Universe in Worship Rituals of the Ede People in Buon Ma Thuot - Central Highland, Vietnam
}

\author{
PhD student Mai Trong An Vinh \\ Hanoi National University of Education
}

\begin{abstract}
Summary
The Ede people's philosophy on the relationship between Humans and the Universe is highly idealistic. They believe that the entire universe consists of 3 layers: The first is the Heaven - the sky in the shape of a great dome covering over the Earth, and at sunset, it is the Sun going back down into a deep earth cave where he lives, while at sunrise, it is the Sun leaving his cave. The same is true for the Moon. The middle layer is the Earth, with a shape of a square, and the last layer is the Underworld. Each of the 3 great layers are inhabited by deities. For the Ede people, the Heaven is ruled by the Ae Die - their supreme deity. Also living there is the god Ae Du, the second supreme deity, who is responsible to teach humans all the rites required in any worship rituals of the Ede people. In addition to the supreme gods, the Ede people also worship numerous other deities such as Yang Hrue (the God of the Sun), Yang Mlau (the God of the Moon), Yang Cu (the God of Mountains), Yang Ee (the God of water), Yang Argin (the God of Wind), Yang Tlua (the God of Rain), Yang Kbua (the God of Life and Fertility), H'Bia Klu (the God of fairies), Yang gram (the God of Thunder), Yang Hma (the God of Swiddens), etc. and many, many other deities that are meant to rule over almost all activities in the daily life of the Ede People. The worship rituals are the culmination of process of accumulating experience and knowledge from the reality of labor and creating of the Ede people since ancient times, with philosophies reflecting the much objective laws on the life of Human in the relationship with the Universe.
\end{abstract}

Keywords: Universe; Universe view; Ede people; rituals; worship.

DOI: $10.7176 /$ RHSS/10-10-02

Publication date:May $31^{\text {st }} 2020$

\section{Introduction}

The Ede people is an ethnic group mostly living in the Central Highland, especially at Buon Ma Thuot. Cultural activities of the Ede people are considerably rich and diversified. Among such activities, worship rituals are relative common and occur rather frequently in the cultural-spiritual life of this ethnic people. Worship rituals reflect the profound universe view of Ede people in daily life. As Vietnam's economic integration with the world is getting more and more powerful, the Ede people in Buon Ma Thuot are granted the opportunity for more intensive interaction and intercourse with other cultures of various other people. This, however, has also caused the cultural identity of Ede people to erode over time, among which was this system of worship rituals. Researching the philosophy of Ede people on the relationship between humans and the universe harbored in their worship rituals may help to gain a partial understanding of the basis for formation and existence of unique form of cultural practice, and to contribute a small part in the preservation and promotion of Ede people's cultural identity in modern times.

\section{Contents}

\subsection{Key concepts}

\subsubsection{Universe view concept}

According to the Fundamental Sino-Vietnamese Dictionary by Dao Duy Anh (2013) the definition of the Universe view is as follows: Universe view is the cognition of human on the Universe'. The 'universe view', in most case, are interpreted into similar meaning with 'worldview'. The Dictionary of philosophical concepts by Tran Van Hien Minh (1966) is a good example for such way of interpretation. The dictionary stated that Universe view is the mental cognition of the universe, the people's conception on the origin, meaning and final purpose of the Universe ${ }^{2}$. The Dictionary of Philosophy by M. Rodentan, P.Iudin et. al. (1976), on the other hand, defined Universe view as a person's system of views, concepts and conception on the entire world around him/her. Generally speaking, it is the collection of all the person's understandings of the world, of natural and social phenomena: the views of philosophy, socio-politics, ethics, aesthetics, science, etc. Philosophical concepts constitute the fundamental core of any worldview, as understood by its literal meaning. The author realizes that while can be defined in many ways, it is apparent that worldview is the combination of all cognitions of humans on themselves and on the world

\footnotetext{
${ }^{1}$ Quoted from Dao Duy Anh (2013), Fundamental Sino-Vietnamese Dictionary, Culture and Information Publishing House, HCMC, pg.782. ${ }^{2}$ Quoted from Tran Van Hien Minh (1966), Dictionary of philosophical concepts, The Seafarer's Book Collection, Nguyen Ba Tong Publishing house, Saigon, Pg.326.

${ }^{3}$ Quoted from M.Rodentan, P.Iudin et. al. (1976), Dictionary of Philosophy, Su That Publishing House, Hanoi, Pg.906.
} 
around them, as resulted from the process of formation, motion and development of themselves. The world view's composition always consists of ideals, believes, knowledge, emotion, reason, etc. Different knowledge and reason would result in different conception. The worldviews, in any case, are always of historical and social nature.

\subsubsection{Worship ritual concept}

\section{* Ritual}

According to the Vietnamese Dictionary by the Center for Lexicography (2007), ritual is the etiquette and procedure of a ceremony ${ }^{\prime}$; the Vietnamese Dictionary by Hoang Phe et. al., Institute of Linguistics of Vietnam (2012) stated that ritual is of the same meaning with rites ${ }^{2}$, and defined rites as etiquettes of a ceremony (in general) and the order in which such etiquettes are meant to be performed ${ }^{3}$. Based on the abovementioned definitions, the author understood rituals as a combination of multiple rites and harbors sense of spirituality. The anthropologist E.B.Tylor stated in his original work Primitive Culture (2013) that the ritual is a means of communication with soul entities ${ }^{4}$ and it is best to put faith in spiritual entities as a minimum definition of religio ${ }^{5}$. Còn A.A Radugina (2002), in the work Encyclopedic Dictionary of Social Studies, stated the followings about the concept of rituals: the ritual appears in theology to demonstrate the effective relationship between everyday life and the supernatural. The ritual is passed down not only in religion but also in life ${ }^{6}$; The ritual is a key components of a people's cultural identity, playing an important role in the understanding of the culture of a clan or a people. Rituals is the full picture of the conduct, psychological identity and ethical norms of a clan and a people. In response to the demands of spiritual life, humans, both in fear of and in desire for blessings of the supernatural, formed the system rituals.

* Worship

The Vietnamese Dictionary by Hoang Phe et. al., Institute of Linguistics of Vietnam (2012) provided the following definitions: Worship is the act of paying homage to a god, a sacred object or the soul of a dead person in the form of rituals or worship according to customs or beliefs ${ }^{7}$ and offering is the act of offering offerings to the dead or spirits of a dead person, according to beliefs or traditional customs ${ }^{8}$; while according to the Dictionary of philosophical concepts by Tran Van Hien Minh (1966), "thò cúng”" (worship-and-offer) is not a word; however, the word "thò phuong" (worship-and-serve) does exist, and understood as a noun exclusive to Christianity, which is defined as the act of honoring and paying homage to the God, accepting him as the Lord of all with omnipotence in all respects ${ }^{9}$.

From the abovementioned opinion and definitions, the author understood worship to be is a mode of spirituality expression of highest universality. Worship takes root in the human's belief of the supernatural existing in the universe, originating from the belief that "Spirits of things", which means every objects, everything possesses a spirit. Therefore, it can be suggested that worship has been around since the formation of human society. Through this thought process, the author reached the understanding that worship rituals are etiquettes and orders of steps rituals and order of steps for conducting a ceremony for the predecessors, ancestors, sages and saints who had great contribution to the country, as well as other supernatural forces, the sacred beings of whom human fears, and from whom people wish pray for their witness to our sincerity.

\subsection{Overview of Buon Ma Thuot and the Ede people in Buon Ma Thuot 2.2.1. Geological location and natural environment Buon Ma Thuot}

Buon Ma Thuot locates on the highlands to the west of the Truong Son Range (Annamite Range), with its administrative territory defined as follows: Adjacent to district $\mathrm{Cu}$ M'Gar to the North; adjacent to the districts Krong Ana and $\mathrm{Cu}$ Kuin to the South; adjacent to district Krong Pak; and adjacent to the districts Buon Don and $\mathrm{Cu}$ Jut to the East $^{10}$. The abundant and fertile land makes the area ideal for an agricultural economy. Buon Ma Thuot is dominated by a monsoon tropical climate, while also under strong influence of the highland climate subregion to the West of the Truong Son range, which cause the area's climate to develop certain unique characteristics.

\footnotetext{
${ }^{1}$ Center for Lexicography (2007), Vietnamese Dictionary, Da Nang Publishing House, Da Nang, Pg.355.

${ }^{2}$ Quoted from Hoang Phe et. al. (2012), Vietnamese Dictionary, Institute of Linguistics of Vietnam, Lexicography and Encyclopedia Publishing House, Hanoi, Pg.872.

${ }^{3}$ Quoted from Hoang Phe et. al. (2012), Vietnamese Dictionary, Institute of Linguistics of Vietnam, Lexicography and Encyclopedia Publishing House, Hanoi, Pg.724.

${ }^{4}$ Quoted from E.B.Tylor (2001), Primitive culture, National Culture Publishing House, Hanoi, Pg.946.

${ }^{5}$ Quoted from E.B.Tylor (2001), Primitive culture, National Culture Publishing House, Hanoi, Pg.947.

${ }^{6}$ Quoted from A.A. Radugina (translated by Vu Dinh Phong, 2002), Encyclopedic Dictionary of Social Studies, Institute for Literature and Art Studies, Hanoi, Pg.326.

${ }^{7}$ Quoted from Hoang Phe et. al. (2012), Vietnamese Dictionary, Institute of Linguistics of Vietnam, Lexicography and Encyclopedia Publishing House, Hanoi, Pg.1222

${ }^{8}$ Quoted from Hoang Phe et. al. (2012), Vietnamese Dictionary, Institute of Linguistics of Vietnam, Lexicography and Encyclopedia Publishing House, Hanoi, Pg.298.

${ }^{9}$ Quoted from Tran Van Hien Minh (1966), Dictionary of philosophical concepts, The Seafarer's Book Collection, Nguyen Ba Tong Publishing house, Saigon, Pg.248.

${ }^{10}$ Quoted from Provincial Party Committee - People's Council - People's Committee of Dak Lak Province (2015), Address of Dak Lak Province, Social Sciences Publishing House, Hanoi, Pg.9.
} 
Each year has 2 distinct seasons: The rainy season: During this season, due to strong influence of West Truong Son climate sub-region, Buon Ma Thuot received great level of precipitation. The season lasts for 6 months, from May to October, matching with the active season of Western and Southwestern winds. The dry season: Lasting for 6 months, from November to April of preceding year, matching the active season of Eastern and Northeastern wind. The area's climate conditions are highly favorable for cultivation of various crops ${ }^{1}$. Buon Ma Thuot is one of the regions with highest natural forest coverage in Vietnam.

\subsubsection{Process of settlement and population distribution of the Ede people}

The title Ede originated from the pronunciation of the Champa people, while the Ede people would call themselves the "Degar" tribe. According to the records written on the Champa note stelae, the ancestor of the Ede people was thought to be the ancient Rang De people. In 1283, the Mongolian went southward to conquere the Champa kingdom. Unable to resist the might of the Mongolian, the Champa king decided to retreat to the Central Highland to hide, and leave the entire lowland territory for the Mongolian to occupy. This migration lead to the birth of a new ethnic group - Anak Jarai, deriving their name from the ethnic group Po Kurung Garai, meaning the group of Rang De people who followed the Champa King Jaya Simhavarman III. The microstate Jarai at the time was an ancient microstate of the Austronesian peoples residing in the Central Highland, including the 2 major ethnic people Gia Rai and Ede formed at around the end of $15^{\text {th }}$ century, and was later divided into smaller ethnic groups at the end of $19^{\text {th }}$ century, which lead to the Ede people's retreat to the South Central Highland area. The Central Highland of Vietnam is considered the ancient homeland of the Ede people. The traditions of Ede people are still predominated over by matrilineality. The major local Ede ethnic subgroups are, namely: the Kpa Ede people, residing mostly at Buon Ma Thuot and the districts Krong Ana, Krong Pac, $\mathrm{Cu}$ Mgar, of Dak Lak province; the Adham Ede people residing mostly at the districts Krong Buk, Cu Mgar, the district-level towns Buon Ho, Krong Nang and a portion of Ea Hleo district of Dak Lak province; the Mdhur Ede people residing mostly at Mdrak district to the east of Dak Lak province, while a small portion reside at Song Hinh district of Phu Yen province; The Bih Ede people is the most ancient Rang De group who still preserve various traces of ancient culture in their language. The subgroup resides mostly along the sides of the rivers Krong Ana and Krong Kno at Dak Nong provinces; the Krung Ede resides mostly at the districts Ea Hleo, Krong Buk of Dak Lak province; in addition, there are also other minor local subgroups, such as: Blo, Dongmak, Hwing, etc. residing sporadically within Dak Lak province. The abovementioned Ede local subgroups barely have any distinction in terms of culture.

\subsection{The philosophy on the relationship between Humans and the Universe reflected in worship rituals of Ede people in Buon Ma Thuot}

\section{The 3-layer universe and "spirits of things"}

The Ede people's philosophy on the relationship between Humans and the Universe is highly idealistic. They believe that the entire universe consists of 3 layers: The first is the Heaven - the sky in the shape of a great dome covering over the Earth, and at sunset, it is the Sun going back down into a deep earth cave where he lives, while at sunrise, it is the Sun leaving his cave. The same is true for the Moon. The middle layer is the Earth, with a shape of a square, and the last layer is the Underworld. Each of the 3 great layers are inhabited by deities ${ }^{2}$. As believed by Ede people, the Heaven is ruled by the Ae Die - their supreme deity. Ae Die is the god who created human and all living creatures, and he's also the one to have gifted human with all the species of crops. Also living the heaven was the god $\mathrm{Ae} \mathrm{Du}$, the second supreme deity, who is responsible to teach humans all the rites required in any worship rituals of the Ede people. In addition, the Heaven is also the home to many other deities. An example is the deities Mtao Kla and Hbia Klu - the divine husband and wife who would bless human for works on swiddens, care for the soil, create mountains, ponds, lakes, rivers and streams, etc. causing the crops on the swiddens to always grow luxuriantly. The Earth is home to the Earth gods (Yang lan), Rice god (Yang mdie); and there are also the gods Mtao Tlua, Kbua Lan, who would usually bring fine weather, protect the crops, protect the animals, guard the rivers and stream, etc. As for the Underworld, the Ede people believe that it is reigned by the two gods Bang Bung and Bang Dai, the divine husband and wife who are responsible to govern the souls of the dead. The souls of the dead, after the undergoing the grave-settling rituals ("bo mả") shall pass on to to reside in the Underworld (both literally and figuratively). For Ede people, if in the world of the livings exist the communities and villages and daily life activities, then the Underworld is just the same, with their own communities and villages and daily life activities. If the villages of the livings are ruled by the village elders and chiefs, the dead's villages are ruled by the gods Bang Bung and Bang Dai in similar manner.

In addition, the Ede people also worship numerous of other deities Yang Hrue (the God of the Sun), Yang Mlau (the God of the Moon), Yang Cu (the God of Mountains), Yang Ee (the God of water), Yang Argin (the God of Wind), Yang Tlua (the God of Rain), Yang Kbũa (the God of Life and Fertility), H'Bia Klu (the God of fairies),

\footnotetext{
${ }^{1}$ Quoted from Provincial Party Committee - People's Council - People's Committee of Dak Lak Province (2015), Address of Dak Lak Province, Social Sciences Publishing House, Hanoi, Pg.9.

${ }^{2}$ Quoted from Provincial Party Committee - People's Council - People's Committee of Dak Lak Province (2015), Address of Dak Lak Province, Social Sciences Publishing House, Hanoi, Pg.769.
} 
Yang gram (the God of Thunder), Yang Hma (the God of Swiddens),etc. and many, many other deities that are meant to rule over almost all activities in the daily life of the Ede People.

\section{Good gods and Evil Gods}

To Ede people, the Universe homes two kinds of deities, namely the Good ones and the Evil ones. Apart from the Good gods mentioned in the previous parts, there are also Evil gods who would always wait for opportunity to bring calamities to the human. A good example is the evil god Yang Brieng (the God of Meteor) a god in the form of a monkey - who would order tigers, leopards, and poisonous snakes to harm human. When the Ede people see meteor falls down on any region, they believe that someone from that area shall soon die a sudden death. Another evil god, Yang Lie, is responsible for all misfortunes and calamities happening to the agricultural activities of human, such as poor harvest, draughts, natural disasters ${ }^{1}$, etc. The Ede people have always believed that worship rituals are the means for humans to communicate with the deities residing in the Universe.

\section{Male stairs and female stairs}

The Ede people's livelihood depends largely on pre-industrial cultivation and animal husbandry activities; and therefore, this people's concept of universe has always been the primitive dualistic cosmology. Among which, the fertility belief is a typical characteristic of the dualistic structure of universe, which originates from the conception that the intercourse of males and females were the origin all and any development in the universe. This concept was found in almost every ethnic people with agricultural civilization, as crop cultivation is their main livelihood. The Ede people in Buon Ma Thuot is a typical example for this belief. For this ethnic people, the staircases leading to their longhouses have crucial symbolic meanings. For Ede people, the longhouses are the space for performance of their various worship rituals, and therefore the staircases to such houses are not simply just an equipment to make way up to the house, but also a "sacred" part. The structure of the longhouses of Ede people always include two separates staircases placed in parallel with each other, both making way to the house, named the Male stair and Female stair. The male stair is placed to the left of the house and is used by only the females of the family, while the female stairs is placed on the left and is for the males of the family to use as well as for the guests. On each of the staircases, the Ede people would normally carve the patterns that resembles mother's breasts and the crescent moon to symbolizes the reign of the females in their matrilineal families. This custom also serves as a way for the Ede people to remind everyone of the role of the women as the family's breadwinners. Before putting the staircase sets to use, Ede people would have to perform an offering ritual to the gods to ask for their protection for all the members of the family as well as for the guests, who would climb the stairs on any days.

\section{Seven is the sacred, miraculous number}

Seven is a number represented almost everywhere in the Universe view of Ede people: They use the number 7 as the scale of timekeeping in the universe: The Ede people calculate time based on the Moon's cycle and the number 7 marks the end for cycle of the moon during the week. This practice is clearly reflected in the agricultural rituals of Ede people, as they look to the moon phase to organize all the worship rituals required an agricultural circle. In addition, there are also many other daily living activities for which the Ede people look to the moon cycle to perform. For the Ede people, the number 7 symbolizes fulfillment and completion; and therefore the quantities of offerings offered to the God in an Ede ritual would almost always be 7. Typically, a worship ritual would usually require 7 wine cups containing the blood of a sacrificed animal mixed with wine, 7 jars of straw wine, 7 dishes of meat from the sacrificed animal, etc., because, for Ede people, the quantity of everything must be 7 to truly reflect the ideal of fulfillment, completion and abundance, and only with that would the gods accept the people's sincerity and fully understood their wishes and prayers, which are meant to be communicated to the gods through the ritual. Moreover, the Ede people have also always considered the number 7 as a sacred and miraculous number, which bring safety, abundance and good fortune. Therefore, a full set of Ede gong usually include 7 pieces; the staircases to the longhouses usually have 7 steps; the soul of the dead, as Ede people believe, must go through 7 stages of transformation before being returned to the living world by reincarnation onto a newborn baby during the naming ritual; 7 days after birth of a child, the family has to perform the naming ritual and the ear-blowing ritual for the baby; during the life of a typical Ede people, he/she would often undergo 7 major rituals for good health; and the farewell rituals for the dead would always be performed 7 days after the dead is buried, etc. Due to the Ede people's view of the universe, all of the abovementioned rites must be performed with the quantities of 7 to ensure abundance, safety and fulfilment. The number 7's symbolic meaning is also represented in many other worship rituals of Ede people, a typical example of which is the K'pan bench welcome ceremony: For the Ede people, K'pan benches symbolize authority and wealth. The bench would always be placed in the longhouses, and is meant to be the seat for the gong players as well as the place for the h'gor drum during worship rituals. The Ede people's crafting of K'pan benches require the following rites: After the ritual of asking for permission from gods to cut down a tree to make the bench, the family head would lead 7 young men bringing 7 seven axes and a shaman to

\footnotetext{
${ }^{1}$ Provincial Party Committee - People's Council - People's Committee of Dak Lak Province (2015), Address of Dak Lak Province, Social Sciences Publishing House, Hanoi, Pg.770.
} 
the tree selected to make the bench. Once the tree is brought down, the family head and the shaman will together walk on the tree 7 times as a rite to chase of the evils. Only after that, would the craftsmen started their work of crafting the K'pan bench. Once the K'pan bench is completed, everyone would work together fletch the K'pan bench to the front of the long house and place one end of the bench on to the edge of the platform of the house. And then, the family head, holding a shield on one hand and a sword on the other, shall walk back and forward on the K'pan bench 7 times as a rite to fend off the evil gods, and then give the K'pan bench a name so as to assure the family's ownership over the K'pan bench. The offerings required in a K'pan bench welcome ceremony often include a bull, and 7 jars of straw wine tied to 7 columns. The biggest jar of wine shall be tied on the most outer column, and on the same column the blood of the sacrificial buffalo shall be spread on in a line of 7 parts. The shaman shall seat on one end of the K'pan bench, holding a long stick and drip its tip into the blood of the sacrificial animal mixed with wine contained in a bronze bowl, and use the stick to spread the blood onto the chair. The K'pan bench is placed to run along the length of the house as a protection seal to protect the wealth of the family.

Again, stemming from their universe view, the Ede people also use the number 7 as the limit of space and time of the universe which was supposed to be infinite, and therefore represent their desire to conquer the universe/the world of nature. This is clearly reflected in the Ede epic The Great Epic of Dam San, where the hero Dam San had expressed his desire to rule over and conquer the realms exclusive to the gods, through his endeavor to find and marry the goddess of the Sun: Dam San jumped of the canopies of the tree enat and the tree knung down to the ground. With one dash, the hero ran passed 7 mountains, and with one jump he went pass 7 waterfalls; it took him a blink of an eye to get back to village, and another to get to his home. Mighty as he was, Dam San's attempt ended with a failure: The hero died and his spirit reincarnated into his grandson, also named Dam San, to take on the hero's dream. Conquering the universe was a long-lasting desire of the Ede people, passed down from generation to generation; however, that desire always remained an unfulfilled wish. In the worship rituals of Ede people, the number seven presents in almost every steps in performance of the rituals, and depends on the specific purpose of each rite in the ritual, the number 7 may represent a different philosophy of life. But, in general, with the universe view of the Ede people, the number 7 is always considered the sacred, miraculous number which bring them peacefulness, abundance and good fortune in the life of people. The superstructure of the Ede society retains the entire system and structures of modes of social consciousness from the traditional social institution from primitive time. The livelihood of Ede people, ever since ancient times, has always been dependent on hunting and gathering and swidden agriculture; therefore, the economy of their community remains unstable and underdeveloped.

\section{Conclusion}

Due to the belief of "spirit of things", the life of a typical Ede person undergoes numerous worship rituals. The Ede people's philosophies on the relationship between Humans and the Universe is embedded into such rituals in order to express and entrust to gods the wishes and desires of the people. The universe view philosophies of the Ede people created a profound sense of sympathy between human and gods, it anthropomorphizes every and any objects and things existing in the life of human. As a result, it creates healthy inspirations that support the life of the Ede people within their community and society. The research on philosophy on the relationship between Humans and the Universe is, therefore, highly beneficial in terms both of theory and practice the preservation and promotion of the values that constitute the cultural identity of the Ede People of Buon Ma Thuot in modern times.

\section{REFERENCES}

1. Dao Duy Anh (2013), Fundamental Sino-Vietnamese Dictionary, Culture and Information Publishing House, HCMC.

2. E.B.Tylor (2001), Primitive culture, National Culture Publishing House, Hanoi.

3. Filosofskij Enciklopedicheskij Slovar' (1983), Encyclopedic Dictionary of Philosophy (3 ${ }^{\text {rd }}$ volume), Moscow Publisher, Moscow.

4. Tran Van Hien Minh (1966), Dictionary of philosophical concepts, The Seafarer's Book Collection, Nguyen Ba Tong Publishing house, Saigon.

5. M.Rodentan, P.Iudin et. al. (1976), Dictionary of philosophy, Su That Publishing House, Hanoi.

6. Hoang Phe et. al. (2012), Vietnamese Dictionary, Institute of Linguistics of Vietnam, Lexicography and Encyclopedia Publishing House, Hanoi.

7. Ngo Duc Thinh, Le Van Ky \& Nguyen Quang Le (2007), Traditional customs of some ethnic minorities in the South Central Highlands, Hanoi Ethnic Publishing House.

8. Nguyen Tuan Triet (2000), Historical development of Malay - Da Dao ethnic group, Social Science Publishing House, Hanoi.

9. Center for Lexicography (2007), Vietnamese Dictionary, Da Nang Publishing House, Da Nang.

10. Provincial Party Committee - People's Council - People's Committee of Dak Lak Province (2015), Address of Dak Lak Province, Social Sciences Publishing House, Hanoi. 
11. Le Trung Vu (1995), Ede Folk Festival, Publishing House of Ethnic Culture, Hanoi.

12. Institute of Culture Studies (2006), Rituals and Customs of ethnic peoples of Central Highland, Social Science Publishing House. 